\title{
SITUATIONAL ANALYSIS AS A FRAMEWORK FOR INTERDISCIPLINARY RESEARCH IN THE SOCIAL SCIENCES
}

\author{
JAN KALENDA
}

\begin{abstract}
This study presents situational analysis as a suitable framework for the development of qualitatively-oriented interdisciplinary research in the social sciences. The article argues that even though interdisciplinary research is considered a coveted form of research practice, it is not particularly well developed in the social sciences. This is partly due to institutional barriers, but also because the majority of disciplines lack a suitable theoretical and methodological framework capable of unifying a variety of theoretical bases and primarily methodological processes. Situational analysis, which is based on the work of second generation grounded theorists, is ideal for this purpose, as it offers a frame for theoretical, epistemological, empirical and methodological interdisciplinarity.
\end{abstract}

Key words: situational analysis; grounded theory; interdisciplinarity; transdisciplinarity; qualitative research; interdisciplinary relations.

A key characteristic of the production of scientific knowledge in late modernity is its increasingly interdisciplinary nature (cf., e.g., Laflamme, 2011; Moran, 2002; Nicolescu, 2011; Nowotny et al., 2001; Sá, 2008; Steinmetz, 2005; Szostak, 2008), which has been heavily reflected in the literature since the mid-1990s (see particularly Gibbons et al., 1994; Hicks \& Katz, 1996; Wallerstein et al., 1998; Ziman, 1994), most frequently in the form of transdisciplinary and interdisciplinary research. ${ }^{1}$

It is considered that a multidisciplinary approach to the creation of scientific knowledge was forced into being by the growing complexity of social phenomena (Buanes \& Jentoft, 2009; Marcovich \& Shin, 2011), the need for holistic solutions to social problems (Schut et

\footnotetext{
${ }^{1}$ We consider transdisciplinarity to mean a relationship between disciplines in which the disciplines overlap with one another. This means that by viewing something through the perspective of other sciences, we can come up with original solutions to old problems while also critically inspecting existing theoretical concepts. Interdisciplinary research, on the other hand, means research involving close cooperation between at least two disciplines, including the synthesis of knowledge and generalizations on a conceptual level. For a more in-depth definition of the terms transdisciplinarity and interdisciplinarity, see Huutoniemi et al., 2010; Klein, 1990, 2011; Moran, 2002; Steinmetz, 2007.
} 
al., 2014; Spielman, 2009) or both (Russell et al., 2008), as well as the fragmentation of some scientific disciplines (Bhambra \& Holmwood, 2011; Holmwood, 2011; Turner, 2000) and the institutional expansion of others (Garforth \& Kerr, 2011; Klein, 1990, 2011).

Many authors (e.g., Brewer, 1999; Gibbons et al., 1994; Wallerstein et al., 1998) see multidisciplinarity as a coveted research practice that aims to enrich our knowledge by enabling the genesis of new knowledge and offering solutions to complex social issues. Despite the emphasis on the necessity and usefulness of this strategy, it is often merely rhetorical, and in practice frequently encounters a number of barriers in scientific research. Petts and colleagues have made the particularly apt claim that "the development of interdisciplinarity is so difficult that true interdisciplinarity is a rare phenomenon" (Petts et al., 2008, p. 593). Numerous other authors (e.g., Jacobs \& Frickel, 2009; Smelser, 2004; Weingart, 2000; Woelert \& Millar, 2013) therefore now point out that there is a significant discrepancy between the avocation of multidisciplinary research in policy documents and actual research policy and research practice.

Attempts to develop multidisciplinary research face a number of barriers (Buanes \& Jentoft, 2009; Schoenberger, 2001; Smelser, 2004). Generally speaking, these relate to the use of modern scientific disciplines as organisational frameworks for the creation of scientific knowledge (Abbot, 2001; Brewer, 1999) on the one hand and the existence of cultural communities to which the researchers have cognitive commitments on the other (Schoenberger, 2001, p. 371). For the purposes of this article, we have divided the various barriers into three groups which mutually permeate and influence one another in social reality:

(1) institutional barriers, the social and organisational structures of the different disciplines, which condition the education system and scientific careers as well as opportunities to publish or create a disciplinary identity (Dubrow, 2011; Petts et al., 2008; Smelser, 2004). These factors are grouped together in such a way that researchers are taught and guided towards a clear research focus within a particular discipline and do not try to develop multidisciplinary research;

(2) external interdisciplinary relations, i.e., the various power relations between the disciplines which not only result in disciplines being sharply delimited against one another, but can also cause one discipline to become subordinate to another (Moran, 2002; Steinmetz, 2007). With this type of barrier, even where researchers are interested in performing multidisciplinary research, they often face the problem that their efforts are restricted by hostile relations between disciplines, which either carefully guard the subject they study or advocate the use of their models and methods to the detriment of the theoretical and research tools used by other sciences;

(3) intellectual barriers, different cognitive schemes that are used in a particular discipline. These mainly include differing ontological assumptions and epistemological foci, which then produce different theoretical and methodological frameworks that do not allow disciplines to be linked up in research practice (Klein, 1996; Nikitina, 2005; Petts et al., 2008).

In this paper, our aim is to provide a suitable theoretical and methodological framework that would enable us to eliminate most type (2) and (3) barriers in qualitative social science research, and thus gradually develop the potential to overcome type (1) barriers. We 
suggest that such a framework is offered by the concept of situational analysis, advocated by the American researcher Adele Clarke, and we show that it has the following: (1) a set of suitable theoretical-methodological or ontological-epistemological frames that ensure integration across social science and humanities disciplines. This enables us to bring together the research processes of sub-disciplines within the framework of a single research project. In other words, it eliminates at least some of the intellectual barriers impeding the development of multidisciplinarity; and (2) it approaches the subject of the research in a completely different way. It does not reduce it to an object in which just a single discipline specializes, but retains the complexity and diversity of the situation being researched. By its very essence, such a research strategy calls for a multidisciplinary approach and thus helps to break down the barriers associated with the cognitive structures of the disciplines; and (3) owing to the nature of its research tools and understanding of the subject of research, this is an alternative means of ensuring cooperation among scientific disciplines that does not lead to hegemonic interdisciplinary research, where one discipline would have to be subordinate to another or would have to cautiously guard its own boundaries. This then limits the number of barriers associated with interdisciplinary relations.

Some important points should be made concerning this aim. We start by assuming that there is clear establishment of a qualitative-or interpretative (Maxwell, 2005) or naturalistic (Lincoln \& Guba, 1985, 1994)-research orientation in the human sciences which we have no need to defend or legitimise here. This has already been done in greater detail and with far greater care by other authors (see, e.g., Denzin and Lincoln, 2005). Moreover, qualitative research strategies can now be found in practically all of the social sciences, and their role following the post-modern, cultural or interpretative reversal has increased, as is evident in the wide range of literature (e.g., Reifová, 2010; Sewell, 2005; Steinmetz, 1999; Wagner, 2003). In the context of the argument we intend to present, it should be stated that our proposed general framework is designed primarily to serve the purposes of qualitative research, not positivist or post-positivist approaches, for which another unifying framework may be needed.

In what follows, we will first briefly describe the key characteristics of situational analysis and how they relate to the creation of a framework for interdisciplinary research in the social sciences and the elimination of intellectual barriers. Then we describe how situational analysis can contribute towards balanced cooperation in terms of power between the social sciences and towards removing the external interdisciplinary relationships that act as barriers.

\section{Situational analysis}

Situational analysis is part of the methodological and epistemological work involved in the "second generation of grounded theory" (Moorse et al., 2009). Its leading exponent is the American researcher Adele Clarke (2003, 2005, 2007, 2009, 2014; Clarke \& Charmaz, 2014; Clarke, Friese, \& Washburn, 2015, 2016, in press), who created and developed situational analysis after 2003 in response to criticism directed at the first generation of this approach, particularly in the work of Barney Glaser and Anselm Strauss (1967) and Juliet Corbin (Strauss \& Corbin, 1990, 1998, 1999), and the postmodern turn in the social sciences. 
Criticism of the work of the first generation of grounded theorists (Bryant, 2002, 2003; Charmaz, 2000, 2006, 2009; Clarke, 2003, 2005; Dey, 1999, 2004; Locke, 1996, 2001) primarily consists of condemnation of its positivist basis, reflected in the following: (1) the limited reflexivity of research practices; (2) treating different results in the data as deviant cases, which results in meanings that do not correspond to the most frequent occurrence of results being marginalized; (3) the excessive generalization of cultural meanings into schematic categories; (4) the implicit promotion of causality in data analysis through the use of an axial model or so-called axial coding; (5) different variants of reductionism in research situations, limiting research to a single central phenomenon; and (6) the rigidity of the analytical procedures used in grounded theory, including a fixation on human actions/ behaviour.

For Clarke (2003, p. 554; 2005, p. xxiv), the postmodern turn embodies a departure from the subject and the emergence in scientific philosophy and the epistemology of phenomena such as an inclination towards discourse, culture and material entities when analysing social facts or emphasizing that a social fact is also discursive, cultural and material in nature. Other characteristics of this turn are an accent on the incompleteness and constructed nature of knowledge and the diverse standpoints those involved hold in relation to events, people, institutions and social processes. Last but not least, the postmodern turn is also characterised by an emphasis on the fragmentary, heterogeneous and complex nature of social reality.

According to Clarke (2007, p. 838; 2014, p. 226), the creation of a situational analysis should enable grounded theory to "push" and "pull" around this turn and lay the groundwork for a far more flexible and more widely applicable methodology based on the very best of the grounded theory tradition. We also assume that it enables the creation of a relatively broad, flexible yet coherent concept that would link up scientific research across the social sciences, leading to much more interdisciplinary research. The reasons for performing situational analysis conceal the effort to address much of the criticism of single-discipline approaches in the social sciences, i.e., the effort to overcome the one-sided/single-discipline view of phenomena, to deal with complex and multi-layered phenomena that call for a multidisciplinary approach or to find alternative ways of analysing data acquired using a variety of research techniques. Situational analysis should therefore not simply lead to the "pushing" and "pulling" of grounded theory around the postmodern turn, but also to the development and deepening of interdisciplinary qualitative research in the social sciences.

Although situational analysis is a new research method which has only developed significantly over the last decade, it now features in a wide range of social sciences: anthropology (Carder, 2008), sociology (Christensen \& Casper, 2000; Friese, 2009, 2010; Washburn, 2013), various fields of psychology (Fulton \& Hayes, 2012; Henckes, 2011; Ness \& Strong, 2013; Schnitzer et al., 2011; Strong et al., 2012), health science (French \& Miller, 2012; Licqurish \& Seibold, 2011; Mills \& Bonner, 2008), social work (Chen, 2011), the study of science and technology (Shostak, 2005) and many others. Proof of the important influence that this concept has can be seen, for example, in the fact that during the last ten years the pivotal book by Adele Clarke (2005), Situational Analysis: Grounded Theory after the Postmodern Turn, has amassed 550 citations in the Scopus academic research database (Scopus, 2015). 


\section{Situational analysis as a framework for theoretical interdisciplinarity}

At the most general level, authors (Clarke, 2005, p. xxiii, Clarke, 2007, p. 860; Clarke, 2009, p. 197; Clarke, 2014, p. 235; Clarke \& Charmaz, 2014, p. xxvi; Clarke \& Star, 2007) see situational analysis as a "package of theory and methodology" that combines the sum of assumptions about social reality (a specific ontology based on pragmatic philosophy) with the innovative methodological processes of grounded theory (analytical tools used to map out research situations). In this respect, situational theory draws on four key sources:

(1) Symbolic interactionism. The key assumption it draws from the work of its leading exponents (Blumer, 1969; Denzin, 1989, 1993; Hall, 1987, 1997) is that social reality arises from the interaction of individuals and their sharing of meaning and ongoing definition of a situation. For Clarke, it is the open link to symbolic interactionism that forms an important ontological assumption that explicitly distances itself from the positivist focus of its predecessors (cf., particularly Glaser \& Strauss, 1967; Glaser, 1978) and blends grounded theory with anti-positivism or with interpretative approaches in the social sciences.

(2) Foucauldian discourse analysis, which enables the researcher to enrich grounded theory at the ontological level in two significant ways. Firstly, it places emphasis on discourse(s) that are part of the situation, since classic grounded theory (see, e.g., Glaser \& Strauss, 1967; Strauss \& Corbin, 1990, 1998, 1999) has a tendency to focus primarily on human actions/behaviour. Secondly, it openly debates the influence of power (so-called micropolitics) both in interaction between actors and also within organisations and social groups, where discourse imposes discipline on the individual and creates a certain form of subjectivity (see, e.g., Foucault, 2000, 2009).

(3) Strauss's social arenas/worlds theory (Strauss, 1978, 1984), which is characterised by an attempt to depict meso-level phenomena in the form of social groups, organisations and various discursive arenas, where meanings are negotiated through the abductive logic of qualitative analysis. In this respect, grounded theory also covers the analysis of social groups and organisations, which extends beyond the micro-social orientation of traditional grounded theory. In response to Strauss, in her early writing Clarke (1991) stresses that social groups are crucial for creating social and individual identities and that commitments to them fundamentally influence human actions.

(4) Study of science and technology (e.g., Latour, 2005; Star, 1989), which emphasizes the material aspects of the situation; in analyses focused solely on the actions of the actors these tend to be marginalized. However, material subjects have an influence on individuals in various different situations, either by specifically restricting/enabling the individual's actions (e.g., movement, communication or the nature of relations between them) or because individuals create distinctive meanings for them which then influence their behaviour (e.g., in that people start to attribute importance to certain material elements).

If we consider these theoretical assumptions from the viewpoint of the integrating potential of situational analysis, the actual theoretical approaches from which it draws are very broad and extend beyond the boundaries of the individual disciplines (anthropology, philosophy, sociology, psychology, history, etc.). Each theoretical tradition considerably 
expands and enriches situational analysis, breaking down any intellectual barriers between the individual disciplines at their theoretical foundations.

First of all, symbolic interactionism, which is closely linked to pragmatic philosophy, constitutes the initial core of much qualitatively-oriented (Denzin, 1989, 1993; Denzin \& Lincoln, 2005) research, making situational analysis compatible with approaches that share similar bases across social sciences. In this theoretical framework, psychology and sociology are particularly close. In both, we can see the disappearance of a boundary delimited by theoretical concepts focused narrowly on the subject of each of these sciences (internal psychic processes versus society), and the process side of the domains' research subjects are highlighted-i.e., the effect of society on the creation of mental processes and vice versa how psychic processes share in the production of social reality.

Stressing the power dimension of interpersonal relationships and the role of discourses in creating subjectivity allows the author to avoid the criticism addressed at older generations of interactiononistic authors who ignored the power relations and discourses involved in shaping the meaning of social reality (Burawoy, 2000). In this regard, situational analysis innovates the project of symbolic interactionism itself and also opens up a space for theoretical cooperation between all disciplines trying to understand power relations between actors and the influence of discourses on human behaviour. In particular, it enables theoretical concepts adopted in sociology to be conveyed into the area of social work or organisational and healthcare studies. As Emmelin Erikson (2013) demonstrated in a health-supporting environment, the creation of meanings of a quality environment is strongly influenced by discourses that are present in the situation and that create normative expectations regarding its current and future shape.

Use of Strauss's concept of social worlds and arenas then expands the cognitive horizon of situational analysis to include a social meso-level. While the majority of qualitative research focuses on the meanings of individuals, situational analysis also pays attention to how meanings are created by collective actors (groups or organisations) and how individuals create commitments towards collective actors. This move enables qualitative studies to be conducted in fields predominantly focused on a particular subject (psychology, healthcare fields or social work) to shift their attention beyond the horizon of that subject and to watch how it is formed by the activity of the organisation and social group.

Last but not least, emphasising material elements presents a further aspect that may be analysed in a research situation and which should be taken into account. Material elements are not only important for understanding the development of science and technology, but they also play an important role in other domains of social reality-work, education, medicine and many others. Situational analysis therefore aims for a much more expressive conceptualisation even in social scientific fields that do not traditionally specialise in them.

The theoretical bases of situational analysis thus not only expand the sphere of those aspects of social reality to be emphasised by the researcher, i.e., they give the researcher an interdisciplinary view of social reality, but also form the basis for cooperation among multiple disciplines and can prompt researchers from various fields (e.g., psychology, architecture, business economics) to cooperate together to understand a particular phenomenon. The synthesis of these four theoretical approaches in situational analysis 
then paves the way for an alternative understanding of the subject of the research, which is another factor that makes situational analysis a suitable framework for interdisciplinary research.

\section{Situational analysis as a framework for epistemological interdisciplinarity}

By changing the approach to the subject of the research, Clarke deals with much of the epistemological criticism brought on by the postmodern turn in the social sciences. According to the author (Clarke, 2014, p. 241), the very situation of exploration should form the basic unit of analysis. The subject of our research should therefore not be a partial phenomenon, e.g., actions, behaviour or experiencing a certain emotion, but the entire situation that encompasses and helps to shape these phenomena.

Although in traditional grounded theory, Strauss and Corbin (1990, p. 163; 1998, p. 184) attempted to resolve the role of the situation to a certain extent by drawing up what they referred to as the "conditional matrix," which portrays the context of the phenomenon as well as the elements that influence human behaviour/actions from outside. Nevertheless, Clarke (2009, p. 208) does not agree that the situation should be conceptualised in this way, as in her own words: "[...] the conditions of the situation are in the situation. There is no such thing as context." By making this provocative statement, the author draws attention to the fact that breaking matters down into phenomenon and context is an arbitrary intervention on the part of the researcher and an act that may be performed and justified at the analytical level but not at the ontological level. Moreover, this basis enables her to show that all the elements in a given situation constitute and influence one another, meaning that they cannot be reduced to a mere phenomenon and its conditional context.

Transferring the analytical focus of the action to the situation will not reduce the phenomenon to a pre-identified expression of human action/behaviour and will not release it from the relations that (combine to) shape it, meaning that the entire situation being researched retains its complexity. Also, in the situation, it enables unique and particular elements to be identified that might not otherwise be considered if the researcher were to concentrate on just one main phenomenon from the very start. It is this approach that allows Clarke to make these broad theoretical starting points which do not separate theory from epistemology and method.

In terms of the development of interdisciplinarity, this epistemological turn is important because the social science disciplines often only study sub-phenomena that relate to the situation, e.g., the mentality of the actors, the way they experience emotions, the material elements in the situation, the discourses to which the people relate, or merely the actions and behaviour of the actors. What makes the situational analysis approach different is its emphasis on the fact that all these elements create the research situation and that we cannot focus on just one of them, as this would break it away from its relations to the other elements of the situation that constitute it. In other words, situational analysis, not only at the level of its theoretical bases, but also in terms of the conceptualisation of the subject of the research, is consistently interdisciplinary, which necessitates the integration of different forms of knowledge about all the aspects that make up the situation. This means that the integration offered by situational analysis is not merely theoretical, but also epistemological. 
The usefulness of epistemological interdisciplinary situational analysis can be demonstrated in a number of cases. If, as one of them, we take interaction in a school classroom, the traditional object of pedagogical research, we should not just analyse the content and forms of interaction (pedagogical communication) but also the emotions that the individuals experience in that situation and the methods they use to regulate them, which is also a traditional object of psychological research. At the same time, we should also take into account how power is used by the individuals in the interaction, and how its use is interpreted and legitimised, which, by contrast, is the focus of attention in the sociological approach. We should also not forget the role played here by the material aspects (classroom layout, proximity/distance of the actors and communicational tools that the individuals have at their disposal), i.e., aspects of the situation that under normal circumstances would only be the subject of study in science and technology. We can see that in highlighting the situation as the basic unit of the analysis, the boundaries between the social science disciplines start to dissolve rapidly.

No less exemplary in this regard are the research surveys by Clarke and Montini (1993) on female contraception, or by Jenifer Fosket (2015) on breast cancer, which analyse all the elements that enter the research situation. On the one hand, we can see in them an effort to incorporate pressure groups (a traditional subject of study in the social movement and political science discipline) or introduce new kinds of treatment (an object of study in science and technologies), and on the other hand expert and moralising discourses that defend or criticise kinds of treatment (a traditional subject in cultural sociology), as well as individual interpretation and the experience of actors (an object of interest in sociology and the psychology of health).

\section{Situational analysis as a framework for methodological interdisciplinarity}

At the methodological level, situational analysis is based on three key sets of tools used to provide the most detailed analysis of the various aspects of the situation being studied (Clarke 2003, p. 554; Clarke, 2005, p. xxii; Clarke, 2009, p. 210; Clarke, 2014, pp. 240-241):

(1) situational maps, serving to portray all the key elements present in the situation being researched regardless of the type of element involved (e.g., individual, social group, behaviour, emotion, discourse, significance or material). With this kind of map, what Jennifer Fosket (2015) refers to as a "thick analysis" is performed, i.e., as detailed as possible a comparison of relations between the individual elements of the situation. In this sense, therefore, situational analysis fulfils the basic premise of grounded theory as understood by Glaser and Strauss (1967, p. vii), i.e., that it is "a general method of (constant) comparative analysis." 2

(2) maps of social worlds and arenas, to identify the key social groups, organisations and arenas in which meanings are negotiated and which are included in the ongoing negotiations. In comparison with situational maps, maps of social worlds and arenas are a means of understanding the actors' situations at the social meso-level, providing an

\footnotetext{
${ }^{2}$ For the original formulation of this proposition, see Glaser (1965). For a substantial development on it, see Hallberg (2006).
} 
understanding of how commitments are formed in individuals, e.g., as identities or in relation to various social groups, or how a situation is influenced by the discourses within a certain organisation.

(3) positional maps, which cover the main positions (not) advocated by those involved in a given situation based on the semantic axes which can be found around central themes or problems identified within the situation being researched.

What is important for us is that all three tools enable the research processes to be integrated not only at the ontological, epistemological and theoretical levels but also at the methodological level. In this respect situational maps are the most general research technique used in situational analysis, and they enable the broadest possible methodological integration. Therefore, they create the best conditions for unifying research strategies. They can be used for the "cartographic analysis" of any kind of situation, even teaching pupils at elementary school, the conduct of doctors in regional hospitals, or researching social movements in rural France or tourism in Bratislava at the end of the nineteenth century. Situational maps can be constructed using any type of material, not just the available texts or recordings of interviews with informers, but also visual data and observation data, etc. Coding and the notes created notes on this diverse information can then be used to construct maps of any situation, capturing all the key elements that make up the situation. This enables situational analysis to integrate various techniques for the qualitative production of data into a single methodological framework.

Maps of social worlds and arenas then represent an analogous means of organising and integrating data at the social meso-level, which is particularly useful for monitoring the development of social groups and organisations. They enable us to track their emergence and demise, as well as transformations in the exclusivity and dominant values which constitute their symbolic boundaries (Lamont \& Molnár, 2002) in addition to the discourses they themselves generate. The research processes of all disciplines interested in the social meso-level can be connected up and unified, i.e., not only sociology and psychology, but also organisational studies, marketing, ecology, urbanism, corporate economics or medical research with groups of patients or healthcare institutions. Moreover, some of the most intensive empirical research over the last decade has been developed through situational analysis.

Last but not least, the use of positional maps gives a deeper understanding of the key positions of the actors identifiable in qualitative data. This kind of methodological tool can again be applied across all disciplines striving to understand how individual actors deal with certain problems or issues. This can be done regardless of whether it involves the position of children in relation to their nursery school teacher, how indigenous peoples see the arrival of Western medicine in Papua New Guinea or what librarians think of the way municipal library information systems work. In these examples, we again see a blurring of the boundaries between pedagogy and psychology, anthropology and health sciences, and computer science and urban studies.

\section{Situational analysis as a federal structure of the disciplines of social science}

In relation to the external barriers of multidisciplinary research in the social sciences and in response to the inspiring work of George Steinmetz (2007), we have developed a keen 
awareness that collaboration between disciplines is not an "innocent undertaking." It may actually take on various power configurations that represent various forms of cooperation based on interdisciplinarity and transdisciplinarity. In this article, we must therefore define the configuration of relations among the social science disciplines that we think are particularly suited to the use of situational analysis as a suitable framework for the development of interdisciplinary research.

In his study, Steinmetz (2007) identified a total of three forms of interdisciplinary research and one variant of transdisciplinary research, which, since he is an analyst of modern empires, he compares to the four patterns of international relations:

(1) Indirect imperial domination, reminiscent of the international political situation of the United States in the 1980s and 1990s when it tried to assert its hegemony in various regions of the world by indirect means without direct territorial subjugation. According to Steinmetz (2007, p. 56), this type of interdisciplinary research leads to situations where less-developed disciplines take over categories, classifications, theoretical approaches and methodological strategies under the influence of disciplines that are far more dominantly established in the social sciences, thereby making them indirectly dependent.

(2) Colonialism, i.e., a situation where one country directly controls the territory of another, such as the British Empire territory in what is now South Africa in the nineteenth century. What is characteristic about disciplinary colonialism is that one discipline controls another and clearly dictates how knowledge should be produced and validated within that discipline.

(3) The Westphalian system of equal sovereign states is the third type of analogy of interdisciplinary cooperation, in which scientific disciplines exist as sovereign entities with clearly differentiated boundaries and none is dominated by another. This kind of relationship is reminiscent of the ties between the states of Europe after 1648, when the system of territorially delimited and sovereign states emerged. In this concept, the individual disciplines carefully monitor their boundaries and tend to define themselves rather than collaborate with one another.

(4) Non-imperial travel and transculturation. The last pattern of international relations applicable to scientific disciplines is similar to the situation after the fall of an empire, e.g., the end of colonial administration in India in the 1960s. If we then look at relations between disciplines from the viewpoint of this analogy, an originally dominant and self-contained discipline loses control of its boundaries, or the disciplines it formerly controlled, providing an opportunity for mutual inspiration, i.e., for bilateral cultural enrichment.

According to Steinmetz (2007, p. 57), the most suitable of these four forms of interdisciplinary cooperation is the last one, as it strives to avoid power (sub)dominance on the one hand and the close guarding of its boundaries on the other, both being mechanisms that, according to him, do not result in any significant mutual enrichment between disciplines or help to develop scientific knowledge.

Although situational analysis is a framework for taking an interdisciplinary approach to research, we do not think that it corresponds to any of the types of interdisciplinarity described by Steinmetz (2007) because of the power relations between fields. In our opinion, situational analysis offers a federal structure of disciplines, reminiscent of relations in 
political federations, e.g., the "Union" in the United States in the nineteenth century or the Hanseatic League of cities in Europe in the sixteenth century, where political sub-units are connected on the basis of shared values, objectives and international policy instruments. If we then apply this concept to cooperation between disciplines (e.g., anthropology, sociology, political science), this would mean that disciplines based on the same values (ontology) and with similar objectives (epistemology) could cooperate together when using shared research tools (methodology).

The federal structure is a suitable "political" framework for interdisciplinarity, as it transcends the boundaries of the various disciplines and does not enforce their individual cognitive interests which could adversely restrict the subject of the research. Instead, it provides researchers with a bolt enabling them to connect their research work with that of other researchers with similar ideas from other disciplines or with a basis for individually controlled research which seeks to respect different cognitive viewpoints without enforcing the primacy of just one of them. Because of this, situational analysis does not lead to the colonialism of other disciplines nor does it result in disciplines cautiously guarding their own boundaries, or in non-territorial dominance.

\section{Conclusion}

Although there are numerous barriers impeding the development of multidisciplinary research in the social sciences, approaches exist that have the potential to overcome them. One of these is situational analysis, which, in the case of qualitative research, enables at least some of these barriers to be broken down. Specifically, these provide ways of eliminating most of the barriers created by the existence of different intellectual bases and external interdisciplinary relations.

Following the work of Katri Huutoniemi et al. (2010, pp. 84-85), situational analysis may be said to represent a strong concept of interdisciplinarity, which blends empirical, methodological, theoretical and epistemological interdisciplinarity to form a single model of scientific research. In practice, this approach results in the connecting up of different kinds of empirical data which in normal circumstances would just be part of one research field greatly enhancing our understanding of empirical reality. Different data collection techniques are then combined to form a coherent methodological system, while the synthesis and development of theoretical concepts from multiple research fields give it a far more holistic and comprehensive picture of social reality. It also leads to an alternative way of understanding phenomena which highlights the fact that the situation from which the analysis must start should be the subject of all social sciences. It is this accentuation of the role of the situation and situationality of all phenomena that leads us to believe that we should understand phenomena through interdisciplinary logic.

However, this distinct focus on the situation does not only bring advantages. Many of the diverse elements present in the situation that needs to be dealt with by the researcher raise questions as to how all the aspects of the situation can be captured and represented. In this regard, and in the spirit of the pragmatic philosophy from which it originates, situational analysis offers the following answers. The researcher should focus mainly on those aspects of the situation that are most useful from the cognitive point of view, i.e., those that we 
know the least about and that have the greatest potential to lead to a new discovery. As for the representation of various meaning positions, in research based on situational analysis the process of cumulating findings may be slower but its scientific value is significantly higher, as it does not involve unreflected (theoretically or epistemologically managed) reductionism and allows for a much deeper understanding of complex reality.

As we noted at the beginning of the study, situational analysis is not and cannot be a general tool for developing multidisciplinarity in all social science fields because it is closely tied to qualitative research methodology, antipositivism and pragmatic philosophy. These three approaches contain the potential for interdisciplinary research based on situational analysis. Since the qualitative approach can only be used in certain kinds of research, this restricts its use as a tool of methodological interdisciplinarity within social science. From the antipositivist orientation stems the limitation in the field of epistemological interdisciplinarity and from the tradition of pragmatic philosophy, of theoretic interdisciplinarity. Despite these understandable limitations, we still believe that situational analysis is a promising approach, which, if used more frequently, could lead to the development of alternative (non-powerbased) forms of interdisciplinarity in the social science.

\section{References}

Abbott, A. (2001). Chaos of disciplines. Chicago: University of Chicago Press.

Bhambra, G. K., \& Holmwood, J. (2011). Introduction and the challenge of interdisciplinarity. Journal of Historical Sociology, 24, 1-8.

Blumer, H. (1969). Symbolic interactionism: Perspective and method. Englewood Cliffs: Prentice Hall.

Brewer, G. D. (1999). The challenges of interdisciplinarity. Policy Sciences, 32, 327-337.

Bryant, A. (2002). Re-grounding grounded theory. Journal of Information Technology, Theory and Application, 44, 25-42.

Bryant, A. (2003). Constructive/ist response to Glaser. FQS Forum: Qualitative Social Research, 4. Available online: http://www.qualitative-research.net/index.php/fqs/article/view/757/1642

Buanes, A., \& Jentoft, S. (2009). Building bridges: Institutional perspectives on interdisciplinarity. Futures, 41, 446-454.

Burawoy, M. (2000). Introduction. In M. Burawoy et al. (Eds.), Ethnography unbound: Power and resistance in the modern metropolis (pp. 1-27). Berkeley: University of California Press.

Carder, P. C. (2008). Managing medication management in assisted living: A situational analysis. Journal of Ethnographic and Qualitative Research, 3, 1-12.

Charmaz, K. (2000). Grounded theory: Objectivist and constructivist methods. In N. Denzin \& Y. Lincoln (Eds.), Handbook of qualitative research (pp. 507- 536). Thousand Oaks: Sage.

Charmaz, K. (2006). Constructing grounded theory. London: Sage.

Charmaz, K. (2009). Shifting the grounds: Constructivist grounded theory methods. In J. M. Moorse et al. (Eds.), Developing grounded theory: The second generation (pp. 127-154). Walnut Creek, CA: Left Coast Press.

Chen, J. (2011). Beyond human rights and public health: Citizenship issues in harm reduction. International Journal of Drug Policy, 22, 184-188.

Christensen, V., \& Casper, M. J. (2000). Hormone mimics and disrupted bodies: A social worlds analysis of a scientific controversy. Sociological Perspectives, 43, 93-120.

Clarke, A. E. (1991). Social worlds theory as organization theory. In D. Maines (Ed.), Social organization and social process: Essays in honor of Anselm Strauss (pp. 17-42). Hawthorne: Aldyne de Gruyter. 
Clarke, A. E., \& Montini, T. (1993). The many faces of RU-486: Tales of situated knowledges and technological contestations. Science, technology and Human Values, 18(1), $42-78$.

Clarke, A. E. (2003). Situational analysis: Grounded theory after the postmodern turn. Symbolic Interaction, 26, 553-576.

Clarke, A. E. (2005). Situational analysis: Grounded theory after the postmodern turn. Thousand Oaks: Sage.

Clarke, A. E. (2007). Grounded theory: Critiques, debates, and situational analysis. In W. Outhwaite \& S. P. Turner (Eds.), The SAGE handbook of social science methodology (pp. 838-885). London: SAGE.

Clarke, A. E. (2009). From grounded theory to situational analysis: What's new? Why? How? In J. M. Moorse et al. (Eds.), Developing grounded theory: The second generation (pp. 194- 233). Walnut Creek: Left Coast Press.

Clarke, A. E. (2014). Grounded theory: Critiques, debates, and situational analysis. In A. E. Clarke \& K. Charmaz (Eds.), Grounded theory and situational analysis. Volume I. History, essentials and debates in grounded theory (pp. 225-251). Thousand Oaks: Sage.

Clarke, A. E., \& Charmaz, K. (2014). Editors' introduction: Grounded theory and situational analysis. In A. E. Clarke \& K. Charmaz (Eds.), Grounded theory and situational analysis. Volume I. History, essentials and debates in grounded theory (pp. xxi xliii). Thousand Oaks: Sage.

Clarke, A. E., Friese, C., \& Washburn, R. (Eds). (2015). Situational analysis in practice: Mapping research with grounded theory. London: Left Coast Press Inc.

Clarke, A. E., Friese, C., \& Washburn, R. (Eds). (2016). Situational analysis: Grounded theory after the interpretative turn. London: Left Coast Press Inc. In press.

Clarke, A. E., \& Star, S. L. (2007). Social worlds/arenas: A theory/methods package. In E. J. Hackett, O. Amsterdamska, M. E. Lynch, \& J. Wajcman (Eds.), The handbook of science and technology studies (pp. 113-137). Cambridge: MIT Press.

Denzin, N. K. (1989). Interpretative interactionism. Newbury Park, CA: Sage.

Denzin, N. K. (1993). Symbolic interactionism and cultural studies: The politics of interpretation. Oxford: Basil Blackwell.

Denzin, N., \& Lincoln, Y. (2005). Handbook of qualitative research. Thousand Oaks: Sage.

Dey, I. (1999). Grounding grounded theory: Guidelines for qualitative inquiry. San Diego: Academic Press.

Dey, I. (2004). Grounded theory. In C. Seale et al. (Eds.), Qualitative research practice (pp. 80-93). London: Sage.

Dubrow, J. (2011). Sociology and American studies: A case study in the limits of interdisciplinarity. American Sociologist, 42, 303-315.

Eriksson, E. (2013). What constitutes a health-enabling neighborhood? A grounded theory situational analysis addressing the significance of social capital and gender. Social Science \& Medicine, 97, 112-123.

Fosket, J. R. (2015). Situating knowledge. In A. E. Clarke, C. Friese, \& R. Washburn (Eds.), Situational analysis in practice. Mapping research with grounded theory (pp. 195-215). London: Left Coast Press Inc

Foucault, M. (2000). Dozerat' a trestat. Zrod väzenia. [Discipline \& punish: The birth of the prison]. Bratislava: Kaligram.

Foucault, M. (2009). Zrození biopolitiky. [The birth of biopolitics]. Brno: CDK.

French, M., \& Miller, F. A. (2012). Leveraging the living laboratory: On the emergence of the entrepreneurial hospital. Social Science \& Medicine, 75, 717-724.

Friese, C. (2009). Models of cloning, models for the Zoo: Rethinking the sociological significance of cloned animals. BioSocieties, 4, 367-390. 
Friese, C. (2010). Classification conundrums: Classifying chimeras and enacting species preservation. Theory and Society, 39, 145-172.

Fulton, J., \& Hayes, C. (2012). Situational analysis-framing approaches to interpretive inquiry in healthcare research. International Journal of Therapy and Rehabilitation, 19, 662-669.

Garforth, L., \& Kerr, A. (2011). Interdisciplinarity and the social sciences: Capital, institutions and autonomy. British Journal of Sociology, 62, 657-676.

Gibbons, M. et al. (1994). The new production of knowledge the dynamics of science and research in contemporary societies. London: Sage.

Glaser, B. G. (1965). The constant comparative method of qualitative analysis. Social Problems, 12, 436445.

Glaser, B. G. (1978). Theoretical sensitivity: Advances in the methodology of grounded theory. Mill Valley: Sociology Press.

Glaser, B. G., \& Strauss, A. L. (1967). The discovery of grounded theory: Strategies for qualitative research. Chicago: Aldine.

Hall, P. M. (1987). Interactionism and the study of social organization. The Sociological Quarterly 28, $1-22$.

Hall, P. M. (1997). Meta-power, social organization, and the shaping of social action. Symbolic Interaction, 20, 397-418.

Hallberg, L. R-M. (2006). The core category of grounded theory: Making constant comparisons. International Journal of Qualitative Studies on Health and Well-being, 1, 141-148.

Henckes, N. (2011). Reforming psychiatric institutions in the mid-twentieth century: A framework for analysis. History of Psychiatry, 22, 164-181.

Hicks, D., \& Katz, S. J. (1996). Where is science going? Science, Technology, \& Human Values, 21, 379-406.

Holmwood, J. (2011). Sociology after Fordism: Prospects and problems. European Journal of Social Theory, 14, 537-556.

Huutoniemi, K. et al. (2010). Analyzing interdisciplinarity: Typology and indicators. Research Policy, $39,79-88$.

Jacobs, J. A., \& Frickel, S. (2009). Interdisciplinarity: A critical assessment. Annual Review of Sociology, 35, 43-65.

Klein, J. T. (1990). Interdisciplinarity: History, theory \& practice. Detroit: Wayne State University Press.

Klein, J. T. (1996). Crossing boundaries. Knowledge, disciplinarities, and interdisciplinarities. Charlottesville: University Press of Virginia.

Klein, J. T. (2011). Une taxinomie de l'interdisciplinarité. Nouvelles Perspectives en Sciences Sociales, 7, 15-48.

Laflamme, S. (2011). Recherche interdisciplinaire et réflexion sur l'interdisciplinarité. Nouvelles Perspectives en Sciences Sociales, 7, 49-64.

Lamont, M., \& Molnár, V. (2002). The study of boundaries in the social sciences. Annual Review of Sociology, 28, 167-195.

Latour, B. (2005). Reassembling the social: An introduction to actor-network theory. Oxford: Oxford University Press.

Licqurish, S., \& Seibold, C. (2011). Applying a contemporary grounded theory methodology. Nurse Researcher, 18, 11-16.

Lincoln, Y., \& Guba, E. G. (1985). Naturalistic inquiry. Newbury Park: Sage publication.

Lincoln, Y., \& Guba, E. G. (1994). Competing paradigms in qualitative research. In N. Denzin \& Y. Lincoln (Eds.), Handbook of qualitative research (pp. 105-118). Thousand Oaks: Sage.

Locke, L. (1996). Rewriting the discovery of grounded theory after 25 years? Journal of Management Inquiry, 5, 239-245. 
Locke, K. (2001). Grounded theory in management research. Thousand Oaks: Sage.

Mills, J., F. \& Bonner, A. K. (2008). Getting to know a stranger - rural nurses' experiences of mentoring: A grounded theory. International Journal of Nursing Studies, 45, 599- 607.

Marcovich, A., \& Shinn, T. (2011). Where is disciplinarity going? Meeting on the borderland. Social Science Information, 50, 582-606.

Maxwell, J. A. (2005). Qualitative research design: An interactive approach. Thousand Oaks: Sage.

Moran, J. (2002). Interdisciplinarity: The new critical idiom. London, New York: Routledge.

Morse, J. M., Stern, P. N., Corbin, J., Bowers, B., Charmaz, K., \& Clarke, A. E. (2009). Introduction. In J. M. Moorse et al. (Eds.). Developing grounded theory: The second generation. Walnut Creek: Left Coast Press.

Nicolescu, B. (2011). De L'interdisciplinarite a La Transdisciplinarite: Foundation Du Dialogue Entre Les Sciences Humaines Et Les Sciences Exactes. Nouvelles Perspectives En Sciences Sociales, 7 , 89-103.

Nikitina, S. (2005). Pathways of interdisciplinary cognition. Cognition and Instruction, 23, 389-425.

Nowotny, H. et al. (2001). Rethinking science: Knowledge and the public in an age of uncertainty. Cambridge: Polity Press.

Ness, O., \& Strong, T. (2013). Learning new ideas and practices together: A co-operative inquiry. Journal of Family Psychotherapy, 24, 246-260.

Petts, J. et al. (2008). Crossing boundaries: Interdisciplinarity in the context of urban environments. Geoforum, 39, 593-601.

Reifová, I. (2010). Obrácené století: „,kulturální obrat“ jako postdisciplinární událost. [Inverted century: the "cultural turn" as postdisciplinary event]. In T. Edwards (Ed), Kulturální teorie: Klasické a současné př́stupy. Praha: Portál.

Russell, A. W., Wickson, F., \& Carew, A. L. (2008). Transdisciplinarity: context, contradictions, and capacity. Futures, 40, 460-472.

Sá, C. M. (2008). Interdisciplinary strategies in U.S. research universities. Higher Education, 55, 536552.

Scopus (2015). Databáze Scopus. Available online: http://www.scopus.com/

Sewell, W. H., Jr. (2005). Logics of history: Social theory and social transformation. Chicago: University of Chicago Press.

Shostak, S. (2005). The emergence of toxicogenomics: A case study of molecularization. Social Studies of Science, 35, 367-403.

Schnitzer, G. et al. (2011). Negotiating the pathways into care in a globalizing world: Help-seeking behaviour of ultra-orthodox Jewish parents. International Journal of Social Psychiatry, 57, 153165.

Schoenberger, E. (2001). Interdisciplinarity and social power. Progress in Human Geography, 25, 365382.

Schut, M. et al. (2014). Towards dynamic research configurations: A framework for reflection on the contribution of research to policy and innovation processes. Science and Public Policy, 41, 207-218.

Smelser, N. (2004). Interdisciplinarity in theory and practice. In C. Camic \& H. Joas (Eds.), The dialogical turn: New roles for sociology in the postdisciplinary age (pp. 43-64). Rowman, Littlefield: Oxford University Press.

Spielman, D. et al. (2009). The art and science of innovation systems inquiry: Application to SubSaharan African agriculture. Technology in Society, 31, 399-405.

Star, S. L. (1989). Regions of the mind: Brain research and the quest for scientific certainty. Stanford: Stanford University Press.

Steinmetz, G. (Ed.). (1999). State/culture: State-formation after cultural turn. New York: Cornell University Press. 
Steinmetz, G. (2005). Scientific authority and the transition to post-Fordism: The plausibility of positivism in U. S. sociology since 1945. In G. Steinmetz (Ed.), The politics of method in the human science: The positivism and its epistemological others (pp. 275-323). Durham: Duke University Press.

Steinmetz, G. (2007). Transdisciplinarity as a non-imperial encounter: For an open sociology. Thesis Eleven, 91, 48-65.

Strauss, A., L. (1978). Social worlds perspective. Studies in Symbolic Interaction, 1, 119-128.

Strauss, A. L. (1984). Social worlds and their segmentation processes. Studies in Symbolic Interaction, 4, 123-139.

Strauss, A. L., \& Corbin, J. (1990). The basics of qualitative analysis: Grounded theory procedures and techniques. Thousand Oaks: Sage.

Strauss, A. L., \& Corbin, J. (1998). The basics of qualitative analysis: Grounded theory procedures and techniques (2nd ed.). Thousand Oaks: Sage.

Strauss, A. L., \& Corbin, J. (1999). Základy kvalitativního výzkumu. (Basics of qualitative research). Boskovice: Albert.

Strong, T. et al. (2012). Counsellors respond to the DSM-IV-TR. Canadian Journal of Counselling and Psychotherapy, 46, 85-106.

Szostak, R. (2008). Classification, interdisciplinarity, and the study of science. Journal of Documentation, 64, 319-332.

Turner, S. (2000). What are disciplines? And how is interdisciplinarity different. In P. Weingart \& N. Stehr (Eds.), Practicing interdisciplinarity (pp. 46-65). Toronto: University of Toronto Press.

Wagner, P. (2003). As intellectual history meets historical sociology: Historical sociology after the linguistic turn. In G. Delanty \& E. F. Isin (Eds.), Handbook of historical sociology (pp. 168-180). London: Sage.

Wallerstein, I. et al. (1998). Kam směřjí sociální vědy? Zpráva Gubenkianovy komise o rekonstrukci sociálních věd. [Open the Social Sciences: Report of the Gulbenkian Commission on the restructuring of the social sciences]. Praha: SLON.

Washburn, R. (2013). Rethinking the disclosure debates: A situational analysis of the multiple meanings of human biomonitoring data. Critical Public Health, 23, 1-14.

Weingart, P. (2000). Interdisciplinarity: The paradoxical discourse. In P. Weingart \& N. Stehr (Eds.), Practising interdisciplinarity (pp. 25-41). Toronto: University of Toronto Press.

Woelert, P., \& Millar, V. (2013). The paradox of interdisciplinarity in Australian research governance. Higher Education, 66, 755-767.

Ziman, J. (1994). Prometheus bound: Science in a dynamic steady state. Cambridge: Cambridge University Press.

Tomas Bata University in Zlín,

Mostní 5139,

76001 Zlín,

Czech Republic

E-mail: kalendajan@gmail.com 